\title{
Correction to: reducing discretion in the Administration of Prison Leave: in search of legitimacy
}

\author{
Elena Larrauri ${ }^{1}$ \\ Published online: 6 January 2020 \\ (C) The Author(s) 2020
}

\section{Correction to: European Journal on Criminal Policy and Research https://doi.org/10.1007/s10610-019-09424-4}

The article Reducing Discretion in the Administration of Prison Leave: In Search of Legitimacy, written by Elena Larrauri, was originally published electronically in SpringerLink on 22 August 2019 without Open Access.

With the author(s)' decision to opt for Open Choice the copyright of the article changed on January 2020 to (C) The Author(s) 2019 and the article is forthwith distributed under the terms of the Creative Commons Attribution 4.0 International License, which permits use, sharing, adaptation, distribution and reproduction in any medium or format, as long as you give appropriate credit to the original author(s) and the source, provide a link to the Creative Commons licence, and indicate if changes were made.

The original article has been corrected.

The online version of the original article can be found at https://oi.org/10.1007/s10610-019-09424-4

Elena Larrauri

elena.larrauri@upf.edu

1 University Pompeu Fabra, Barcelona, Spain 